\title{
Pulse Current Treatment Effect on the Strength of Reinforcing Steel and Its Weld Joint under Impact Loading
}

\author{
L. Kruszka, ${ }^{a}$ G. V. Stepanov, ${ }^{\text {b }}$ V. I. Zubov, ${ }^{\text {b }}$ and A. I. Babutskii ${ }^{b}$ \\ ${ }^{a}$ Military Technical Academy, Warsaw, Poland \\ ${ }^{\mathrm{b}}$ Pisarenko Institute of Problems of Strength, National Academy of Sciences of Ukraine, \\ Kiev, Ukraine
}

УДК 539.4

\section{Влияние обработки импульсным электрическим током на прочность арматурной стали и ее сварного соединения при ударном нагружении}

\author{
Л. Крушка ${ }^{a}$, Г. В. Степанов ${ }^{6}$, В. И. Зубов ${ }^{б}$, А. И. Бабуцкий \\ а Военно-техническая академия, Варшава, Польша \\ ${ }^{\sigma}$ Институт проблем прочности им. Г. С. Писаренко НАН Украины, Киев, Украина \\ Приведень результаты испьтаний на статическое и ударное растяжение образцов из \\ строительной арматурной стали в состоянии поставки, образиов со стылковым сварнызм \\ соединением в рабочей части, а также образиов, предварительно обработанных пропус- \\ канием импульсного электрического тока выссокой плотности. Показано, что повыциенная \\ скорость деформации вызывает увеличение прочности, а обработка импульсным электри- \\ ческим током существенно влияет на прочность и пластичность металла с дефектами в \\ области сварного шва как при статическом, так и при ударном растяжении.
}

Ключевые слова: импульсный электрический ток, ударное растяжение, арматурная сталь, сварное соединение.

Introduction. Strength and performance of structural components are estimated by calculation models with the account of material properties as well as influence of loading conditions and manufacturing technology. One of the major parameters, characterizing loading conditions, is a strain (or loading) rate, while weld technology and further weld treatment are of primary importance for the strength of the structure. Joint welding usually fails to avoid pores, slag inclusions, and other defects [1], which exerts a considerable effect on the strength.

Quality of weld joints is one of the important factors, determining performance and life of engineering structures. As is seen from the literature, this problem has not been adequately investigated, which makes the development of these studies currently central.

The present communication cites the results of experimental evaluation of the strength and plasticity of as-received reinforcing steel specimens and steel specimens with welds in their test portion under static and impact tension. The effect of 
high-density pulse current treatment on the strength and plasticity of the base metal and weld joint was additionally investigated. It looks rather promising for enhancing these characteristics [2].

Test Specimens. Test specimens were prepared from St3SX reinforcing steel of Polish production with the following chemical composition: $C \approx 0.2 \%$, $\mathrm{Si}<0.07 \%, \mathrm{P}$ and $\mathrm{S}<0.05 \%$.

The strength and plasicity of as-received reinforcing steel under static tension were determined by testing its specimens prepared according to GOST 1497-84 (test portion diameter and length are $6 \mathrm{~mm}$ and $35 \mathrm{~mm}$ ), specimens with the weld joint were cut in accordance with GOST 6996-66 (test portion diameter and length are $6 \mathrm{~mm}$ and $70 \mathrm{~mm}$ ).

The schemes of making steel specimens and specimens with the weld joint from 20-mm-diameter bars are presented in Fig. 1. Bars for specimens with the weld joint were welded by alternating current $(100 \mathrm{~A})$ in a $\mathrm{CO}_{2}$ protective atmosphere with an SpG3S electrode wire (PN-88/M-69420).

Base metal specimens, specimens with the weld joint, and specimens pretreated by pulse current were tested on a BISS universal machine at a strain rate of $10^{-2} \mathrm{~s}^{-1}$.

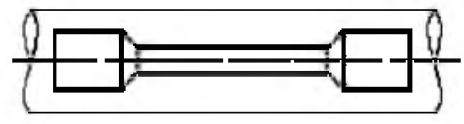

$a$

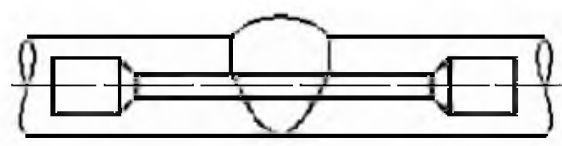

$b$

Fig. 1. Base metal specimen (a) and specimen with the weld joint $(b)$ for standard tensile tests.

Experimental construction of true stress-strain relations under impact tension is complicated by the fact that in the specimen with a short test portion, a nonuniform stress-strain state develops, being the result of the wave nature of specimen loading and loading of circuit elements (propagation, reflection, and interaction of elastoplastic waves). The stress-strain state in the test portion close to the uniform one (basic condition of plotting the stress-strain relation under impact tension) is established after 3-5 paths of longitudinal waves along the specimen, which requires specimens with a short test portion. The influence of radial oscillations of the specimen is reduced by decreasing its diameter.

Therefore, investigations under impact tension made use of specimens with a short test portion (diameter and length are $4 \mathrm{~mm}$ and $10 \mathrm{~mm}$ ) that maintains the stress-strain state uniformity in the volume of their test portion and undistorted registration of stresses and strains in this volume. The deviation of the stress-strain state from the uniform one is within allowable ranges $[3,4]$.

The scheme of impact tension (Fig. 2) is the modification of the Hopkinson split pressure bar. The impact of free-falling striker 4 over anvil 5 fixed at the end of loading rod 3 generates a longitudinal wave of elastic stresses, behind its front, 
the rate is approximately equal to the rate of the striker. The travel of an elastic wave through the area of connection with the head of specimen 3 and further to the dynamometer gives rise to the specimen tension.

The cross-section of the loading rod is much larger than the cross-section area of the specimen test portion, which causes the displacement of the loaded specimen head with a rate, being about two times higher than the striker rate.
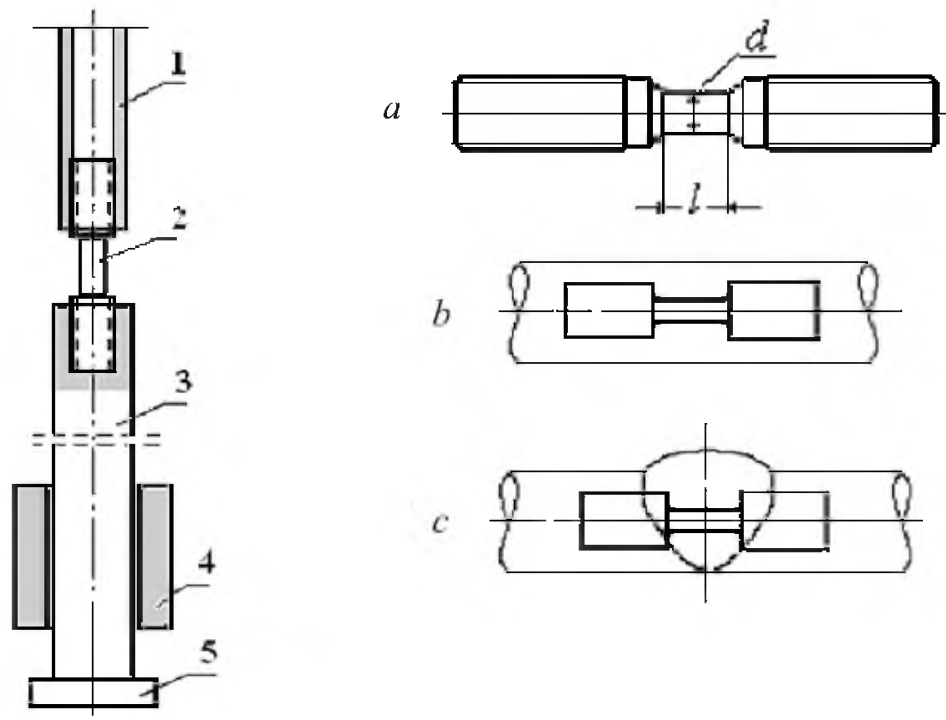

Fig. 2. Scheme of impact tension, specimen $(a)$ and bars for its preparation $(b)$ and $(c)$.

Scheme of Pulse Current Treatment. The scheme of the generator used for the treatment of specimens by pulse current passage is shown in Fig. 3. It includes high-voltage source $l$ (up to $5 \mathrm{kV}$ ), a bank of capacitors $C$ (total capacity up to $1200 \mu \mathrm{F}$ ), mechanical key $P$ and ballast resistor $R$. The amplitude of pulse current and its variation were registered by Rogovsky belt 3 , its signal was fed to the high-speed analog-digital converter of PC.

Specimen 2 was connected to the busline with one head, the second head was connected to the cylinder bottom. The cylinder was connected to the discharge cercuit with its end to provide symmetrical action of ponderomotive forces on the specimen and prevents its flexure.

The characteristic diagram of discharge current variation with time is also presented in Fig. 3.

Static Test Results for Standard Specimens. The pulse current treatment consisted in passage through the specimen one or three current pulses generated by capacitor bank discharge $(750 \mu \mathrm{F})$. Discharge current was varied by changing the initial voltage on capacitor bank terminals. In each pulse current treatment three specimens were tested. Averaged test results are summarized in Table 1.

As follows from the results, passage of one current pulse results in an increase in strength as compared to as-received steel within $4-6 \%$. Three pulses give an increase in this characteristic only by $2-5 \%$. 
$\mathrm{T}$ a b 1 e 1

\section{Results of Static Tests}

\begin{tabular}{|c|c|c|c|c|}
\hline \multirow[t]{2}{*}{ Metal state } & \multicolumn{2}{|c|}{ Pulse current treatment } & \multirow{2}{*}{$\begin{array}{c}\text { Yield stress, } \\
\mathrm{MPa}\end{array}$} & \multirow{2}{*}{$\begin{array}{l}\text { Ultimate strength, } \\
\mathrm{MPa}\end{array}$} \\
\hline & Current $I, \mathrm{kA}$ & Number of pulses & & \\
\hline \multirow[t]{4}{*}{ As-received } & \multicolumn{2}{|c|}{ Without treatment } & 499 & 510 \\
\hline & 56 & \multirow{3}{*}{$1 / 3$} & $527 / 523$ & $543 / 535$ \\
\hline & 100 & & $521 / 508$ & $539 / 521$ \\
\hline & 141 & & $520 / 520$ & $536 / 535$ \\
\hline \multirow[t]{4}{*}{ Weld joint } & \multicolumn{2}{|c|}{ Without treatment } & 232 & 282 \\
\hline & 56 & \multirow[t]{3}{*}{$1 / 3$} & $290 / 331$ & $334 / 406$ \\
\hline & 100 & & $340 / 324$ & $453 / 400$ \\
\hline & 141 & & $242 /-$ & $273 /-$ \\
\hline
\end{tabular}
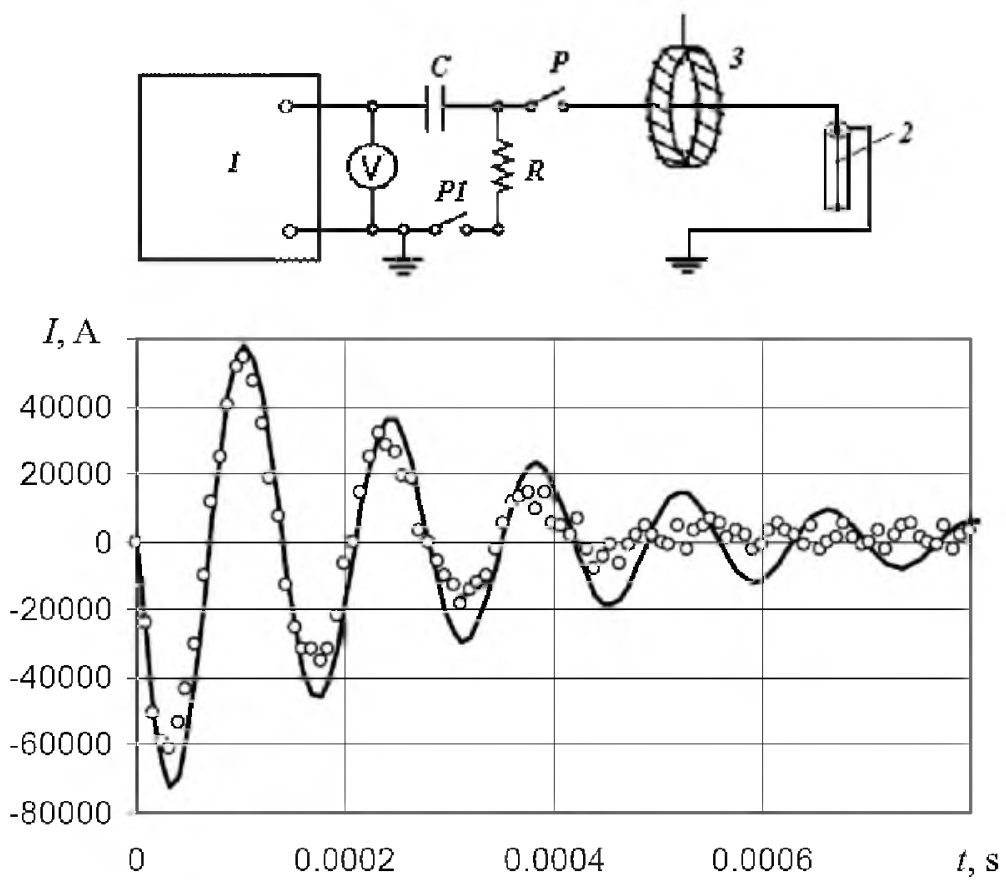

Fig. 3. Scheme of the pulse current treatment of the specimen and characteristic discharge current-time diagram (approximation - solid line, experiment - points).

The pulse current effect on the strength of the weld metal looks more essential. Thus, passage of one current pulse leads to an increase in the yield stress of the weld metal by $25-47 \%$ and in the ultimate strength by $18-61 \%$. Three current pulses result in an increase in the yield stress by $40-43 \%$ and the ultimate strength by $42-44 \%$ depending on treatment conditions. One should note the wide scatter in test results for the specimens with the weld joint, which is associated with the presence of welding defects (Fig. 4). Probably, the pulse current treatment leads to a decrease in the stress concentration factor in the vicinity of defects, which increases the strength of a defect-containing weld. 
Thus, the pulse current treatment of as-reccived reinforcing stecl leads to an inconsiderable increase (about 5\%) in its strength under static tension. However, the treatment of the weld joint considerably increases (up to 60\%) strength, bringing its values closer to the values for the as-received metal.

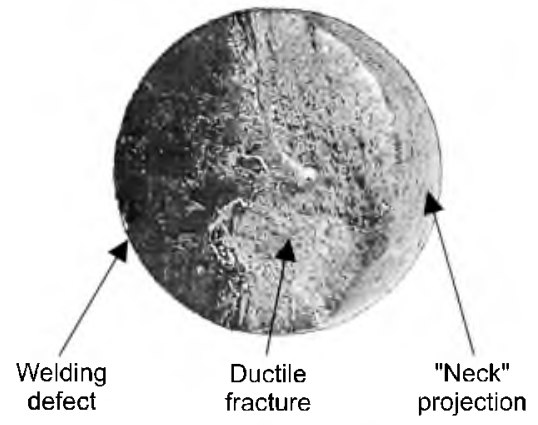

Fig. 4. Fracture of the specimen with the weld joint (side view).

Test Results for the Specimens with a Short Test Portion. Comparison of test results for identical specimens under static and impact tension permits determining the effect of a strain rate on the strength and plasticity of materials in a uniaxial stress state. The tests under impact tension were performed on a vertical impact machine with a falling weight (nominal tension rate is $10 \mathrm{~m} / \mathrm{s}$, strain rate $\left.\dot{\varepsilon}=10^{3} \mathrm{~s}^{-1}\right)$. Static tension was effected by a screw loading device $\left(V_{0}=1.2\right.$ $\mathrm{mm} / \mathrm{min}$ and $\dot{\varepsilon}=10^{-3} \mathrm{~s}^{-1}$ ) mounted on the vertical impact machine. Characteristic diagrams under static and impact tension of as-received metal specimens and specimens with the weld joint in their test portion, used to determine strength, are shown in Fig. 5.

To estimate the pulse current effect on the strength and plasticity of steel, identical as-received metal specimens and specimens with the weld joint in the test portion were tested under static and impact tension. Identical specimens with a short test portion $(d=4 \mathrm{~mm}$ and $l=10 \mathrm{~mm}$ ) and thread-cutting heads made from cylindrical bars of an as-received metal and bars with the weld joint, produced by the above technology, were used for correct assessment of the metal strength under static and impact tension (Fig. 1). Small sizes of the test portion provide the stress-strain state close to the uniform one under static and impact tension at a rate of $10 \mathrm{~m} / \mathrm{s}$.

The specimens were treated by pulse current passage with a capacitor bank discharge $(600 \mu \mathrm{F})$ charged up to a preset voltage $U_{0}=2-4 \mathrm{kV}$. The amplitude of decaying sinusoidal current and period of oscillations (145 $\mu \mathrm{s})$ were measured by the Rogovsky belt.

As numerical simulation results demonstrate, pulse current passage through the specimen does not cause considerable nonuniformity of current distribution in a homogeneous metal due to a skin effect. The calculated difference in a maximum density of sinusoidal current on the surface and along the test portion axis of a 4-mm diameter specimen does not exceed $5 \%$, which does not produce noticeable temperature nonuniformity over the cross-section of the specimen. 

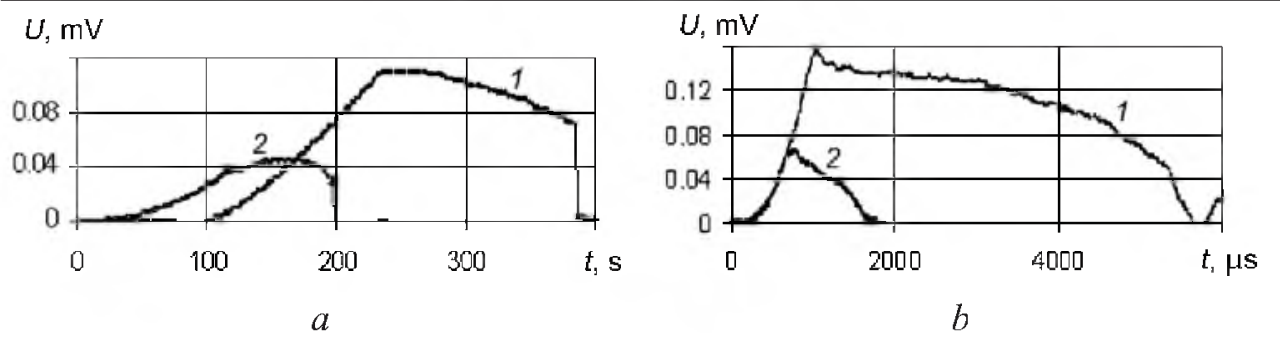

Fig. 5. Characteristic electric signal-time diagrams under static $(a)$ and impact $(b)$ tension of as-received metal specimens ( 1 ) and specimens with the weld joint in the test portion (2).

Test Results and Discussion. As-Received Metal. For as-received metal specimens with a short test portion, an averaged plastic extension and necking under static tension (18.6 and 57.9\%) are somewhat lower than under the impact one $(22.4$ and $60 \%)$. The yield stress under impact tension $(587 \mathrm{MPa})$ is $25 \%$ higher than under the static one (465 MPa).

The pulse current pretreatment of specimens does not practically influence the plasticity (relative extension $\delta$ and relative necking $\psi$ after fracture), and the yield stress $\sigma_{Y}$ increases by $12 \%$ with current density (Fig. 6).
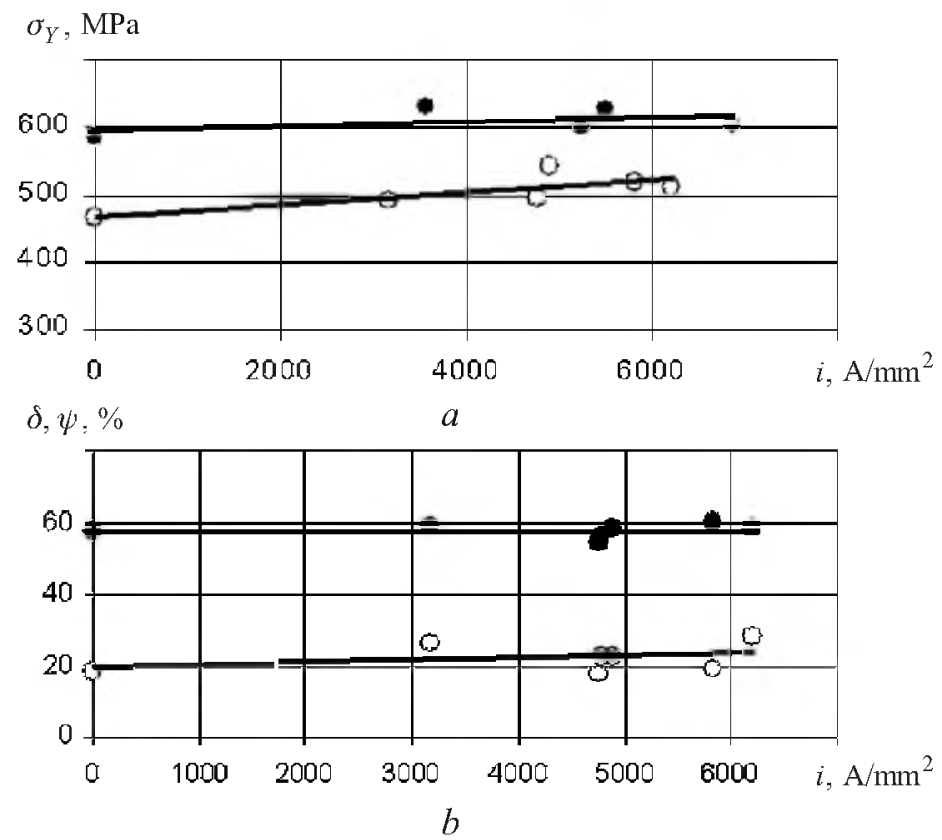

Fig. 6. Yield stress $\sigma_{Y}(a)$ (open points - static tension and solid points - impact tension) and plasticity $(b)$ ( $\delta$ - open points and $\psi$ - solid points) under impact tension vs current density for as-received metal specimens.

Specimen with the Weld Joint. The plastic strain and yield stress of specimens with the weld joint and a short test portion under static and impact tension are much lower than those of as-received steel specimens. The wide scatter of plasticity and strength values is probably caused by different effects of welding defects present in all specimens with the weld joint. 
The relative extension and necking of specimens with the weld joint and a short test portion after fracture under static tension (5.7 and $21.5 \%$ ) are much lower than under the impact one (8.6 and 26.9\%). The yield stress under impact tension $(240 \mathrm{MPa})$ is $20 \%$ higher than under the static one (Fig. 7).
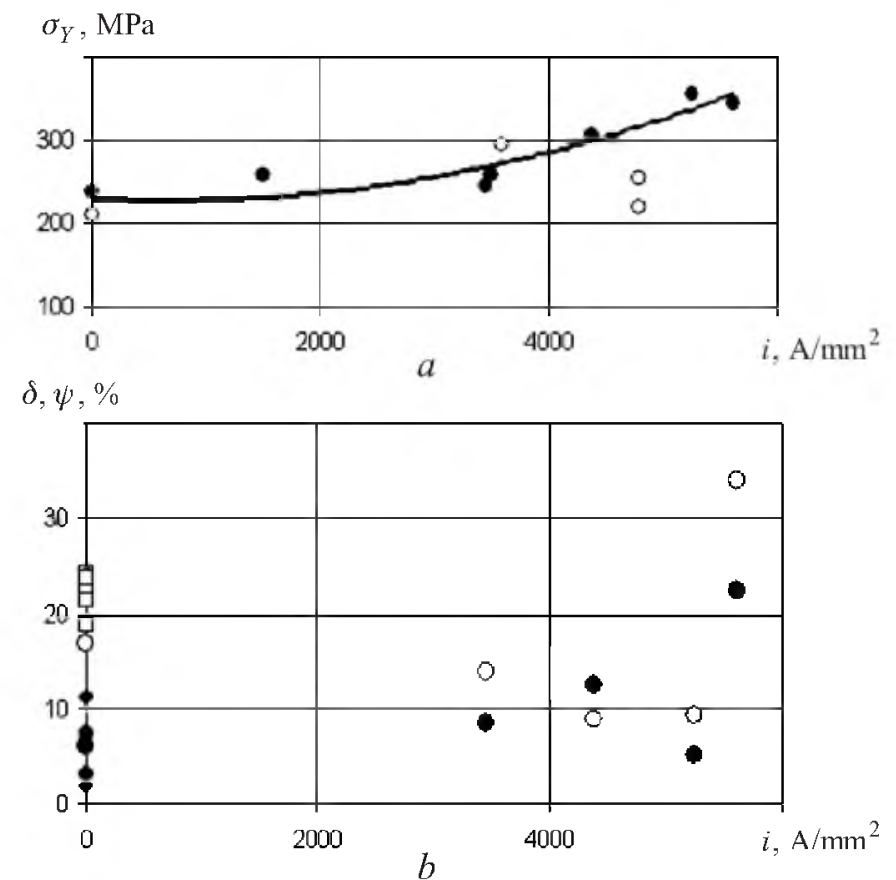

Fig. 7. Yield stress $\sigma_{Y}(a)$ (open points - static tension and solid points - impact tension) and plasticity $(b)$ ( $\delta$ - solid points and $\psi$ - open points) under impact tension vs current density for specimens with the weld joint.

Plasticity and yield stress values increase during the pulse current treatment, which can be the result of a positive local temperature growth effect that causes a decrease of stress intensities in the vicinity of crack-like defects due to plastic strains near them and other stress concentrators. The pulse current pretreatment of a weld joint metal at a current density of about $5 \mathrm{kA} / \mathrm{mm}^{2}$ increases its dynamic yield stress by about 1.5 times as compared to an untreated weld joint metal.

As follows from the analysis of test results, the level of strength and plasticity of specimens with the weld joint decreases. Macrodefects (pores) are clearly visible on the fracture surface, their effect is seen as strain localization in their vicinity. The pulse current pretreatment of such specimens causes a considerable increase in strength and plasticity. Under impact tension, the scatter in data is much smaller than under the static one (Fig. 7).

An essential effect of the pulse current treatment on the strength and plasticity over the area of the weld joint is most likely associated with local stress relaxation and plastic strains reducing the local stress concentration factor at increased localized heating in the vicinity of defects (average heating temperature does not exceed $150^{\circ} \mathrm{C}$, which cannot influence the yield stress). Localized heading is effected by pulse current passage at the growth rate ensuring a temperature 
gradient in the vicinity of defects. At an insufficient current growth rate, the temperature gradient decreases as a result of heat conduction effects.

Conclusions. As the rest results for standard specimens without the weld joint demonstrated, pulse current passage leads to an inconsiderable increase in strength (up to $6 \%$ ) as compared to an as-received metal. Current passage through specimens with the weld joint produces an increase in the yield stress (up to 47\%) and ultimate strength (up to 61\%) of the weld joint metal.

An increase in a strain rate up to $1000 \mathrm{~s}^{-1}$ under impact tension of as-received metal specimens with a short test portion causes an increase in the yield stress without noticeable plasticity changes.

The pulse current treatment of as-received metal specimens causes an increase in the yield stress under static tension, which is less significant under impact tension without noticeable plasticity changes.

The pulse current treatment of specimens with a defect-containing weld joint and a short test portion produces a considerable increase in the yield stress and reduces the scatter of data under impact tension without a noticeable influence on plasticity.

The pulse current effect on the strength and plasticity of the metal over the area of the weld joint can be explained by stress relaxation and microstrains in the vicinity of defects.

In the tests of specimens with a reduced cross-section area (increased relative weld defect sizes) the influence of these defects becomes more pronounced.

\section{Резиме}

Наведено результати випробувань на статичний та ударний розтяг зразків із будівельної сталі у стані поставки, зразків зі стиковим зварним з'єднанням у робочій частині та зразків, що попередньо обробляли пропусканням імпульсного електричного струму високої густини. Показано, що підвищена швидкість деформації призводить до збільшення міцності, а обробка імпульсним електричним струмом суттєво впливає на міцність і пластичність металу 3 дефектами в області зварного шва як за статичного, так і ударного розтягу.

1. G. P. Karzov, V. P. Leonov, and B. T. Timofeev, Welded High-Pressure Vessels: Strength and Service Life [in Russian], Mashinostroenie, Leningrad (1982).

2. G. Stepanov, A. Babutsky, and L. Kruszka, "Metals behavior under passage of impulse electric current," J. Phys. IV France, 110, 577-582 (2003).

3. G. V. Stepanov, Elastoplastic Deformation and Fracture of Materials under Pulse Loading [in Russian], Naukova Dumka, Kiev (1991).

4. G. V. Stepanov, "Strength of metals at high strain rates," Strength Mater., 34, No. 3, 214-218 (2002).

Received 24. 06. 2008 